Kinestetik : Jurnal Ilmiah Pendidikan Jasmani 5 (2) (2021)

Kinestetik : Jurnal Ilmiah Pendidikan Jasmani

https://ejournal.unib.ac.id/index.php/kinestetik/index

DOI : 10.33369/jk.v5i2.17782

\title{
PROFILE OF MAXIMUM VOLUME LEVEL OF TAKRAW ATHLETE STATE HIGH SCHOOL OF SPORTS ABILITY (SMANKO) BENGKULU PROVINCE
}

\author{
Feby EIra Perdima*1, Suwarni ${ }^{2}$ \\ ${ }^{1}$ Physical Education, University Dehasen Bengkulu, Indonesia, \\ ${ }^{2}$ Management, Universitas Dehasen Bengkulu, Indonesia
}

\section{Article Info}

Article History :

Received :June 2021

Revised : June 2021

Accepted : June 2021

Available online: June 2021

Keywords:

Sepak takraw, SMANKO, VO2max

\begin{abstract}
The purpose of this study was to determine the maximum oxygen uptake of athletesSepak takrawSports Talent State High School (SMANKO) Bengkulu Province. This study is a descriptive study. Collect data using a survey method with tests and measurements. This instrument is used to measure the maximum $\mathrm{VO} 2$ test using the Bleep test. The subject of this research is AthleteSepak takrawThe State High School of Sports Talent (SMANKO) of Bengkulu Province totaled 11 athletes. The data analysis technique used in this research is quantitative description analysis presented in percentage form. The conclusion that can be drawn is that the athletes' maximum oxygen uptake is as follows: In the very good category there are 0 athletes $(0 \%)$, in the good category there are 0 athletes $(0 \%)$, the moderate category there are 11 athletes $(100 \%)$, in the poor category there are 0 athletes $(0 \%)$ and very bad category there are 0 athletes $(0 \%)$
\end{abstract}

Corresponding address: Jl. Meranti No.32, Sawah Lebar, Kec. Ratu

Agung, Kota Bengkulu

* Corresponding email: feby.elra@unived.ac.id
ISSN 2685-6514 (Online)

ISSN 2477-331X (Print) 


\section{INTRODUCTION}

Sport is an activity that is mostly carried out by the community, its existence is no longer underestimated but has become part of people's lives. Because today's sport has become a trend in society, both parents, teenagers and children. Because this sport has meaning not only for health, but more than that, namely as a means of education and even achievement

Sports achievements can foster a sense of national pride, because they can elevate the dignity of a nation. according to(Ministry of Sports, 2005)In Law no. 3 of 2005 article 1 paragraph 4 explains that: "Sports are all systematic activities to encourage, foster and develop physical, spiritual and social potential". Based on the quote, one type of sport that encourages, fosters and develops physical, spiritual and social potential is through Sepak Takraw.

Sepak takraw is a sport game in which there are movements from other branches such as football, handball and gymnastics, this game is carried out by two opposing teams. Each team consists of 3 players who are separated from the net. As a team sport, sepak takraw is a game played on a rectangular, level field, either open or out door, or closed, either on a hard court or a sand court with and free from obstacles.

according to (Sofyan, 2015)Sepak takraw is a historic and cultural sport of the nation and the state of nature and Indonesian produce. Sepak takraw or soccer sport has been played in the era of the kingdoms of Sriwijaya, Majapahit and Goa. In Indonesia, there are a number of regions where soccer games are popular and are played in various circles of society. Along with the times, the function of sepak takraw has expanded not only as a (technical) in the community but also as a sports facility, as a means of physical, mental and social (ethical) education and a means of achieving an achievement..

One of the factors in the development of sepak takraw in Indonesia cannot be separated from problems, nursery and coaching students, from early childhood development will be born in the next generation who will make Indonesia proud in the future, coaches, coaches, branch managers, provincial administrators, and parents. the PB PSTI organization strives to develop sepak takraw in Indonesia, one of which is by organizing competitions and fostering the sport of sepak takraw.

$$
\text { The explanation above, }
$$

Bengkulu Province also conducts coaching at the youth level, namely the State High School of Sports Talent (SMANKO) in collaboration with the Provincial DIKNAS, Provincial DISPORA and PSTI Bengkulu Province. Based on information from Mr. Erizal as the head coach of the Sepak Takraw branch at the State High School of Sports Talent (SMANKO) 
Bengkulu Province. This Sports Talent High School has facilities for a Volleyball field (Indor), a basketball court, a fitness room, a futsal field, a takraw field and a multipurpose building that is used as a training ground for other sports activities.

Over time, sepak takraw athletes tend to experience a decline in achievement. This can be seen from the achievements in national-scale tournaments, such as the 2018 POPWIL in Solo, which did not perform well, only placing third. Both in singles and doubles so that they do not qualify for POPNAS, where there are no more players who are able to compete with other players, especially athletes from the island of Java. Sepak takraw athletes tend to use an aerobic energy system, however, sepak takraw requires an anaerobic energy system. This aerobic system will be seen from the length of time to complete the game. Then one of the characteristics of this sepak takraw game is required to move continuously (high mobility).

A player who has high technical ability also requires maximum ability from every component of physical condition. Regular physical exercise will be able to stimulate all body systems so that they can maintain the body in a healthy state(Candra, 2020). Given the extent that must be mastered is wider than the reach of the hands, feet and body, the athlete must step here and there so that we are in the best position to pass to the fider and the fider makes the right pass for the athlete to roll or smash in a direction that is difficult for the opponent. . To be able to do all of that, of course, athletes are required to have good physical condition with all the elements that play a role in it speed, strength, endurance, and so on. One of the factors that affect the physical condition is VO2 max capacity. according to(Anusopati et al., 2015) VO2Max is the body's system that transports oxygen by pumped blood from the lungs to the muscle tissue. A person who often exercises or does exercise may have good stamina by having a higher VO2Max value, so that he can do more strenuous exercises, and has a higher concentration power. The higher the concentration of a student in learning, the better the student in obtaining achievement

The high and low physical condition of a person can also be seen from the high and low levels of $\mathrm{VO} 2$ max (maximum oxygen volume) which affect the physical abilities of athletes and non athletes. VO2 max has a very big role in determining athlete achievement. so VO2 max is one of the important factors in running an exercise program without experiencing excessive fatigue. The high and low endurance of a person will be influenced by the high and low VO2 $\max$.

Factors affecting Vo2max according to (Nirwandi, 2018)namely, among others: Heart The heart is a 
hollow, muscular organ whose function is to pump blood through the vascular system of the heart. The heart moves with strong and regular contractions of the muscle fibers that make up the walls of its cavities. Cardiac Lung System "Oxygen is lifted from the atmosphere to the body cells by the cardiac pulmonary system. During exercise this system functions to support aerobic metabolism by increasing the tempo of oxygen delivered to active muscles. The cardiopulmonary system consists of four components: lungs, heart, blood vessels and blood. The heart-lung system plays a major role in how the body reacts to exercise.

\section{METHODS}

The methodology in this study is survey research, the purpose of this research is to see how the level of VO2MAX ability of sepak takraw athletes at the 2018 State High School with Sports Talent (SMANKO).(Siyoto \& Sodik, 2015)explained "Population is a generalization area consisting of objects or subjects that affect certain quantities and characteristics determined by researchers to be studied and then drawn conclusions". The population in this study were athletes from Bengkulu City. Consisting of 11 takraw athletes from the State High School of Sports Talent (SMANKO).(Siyoto \& Sodik, 2015)the sample in the study amounted to 11 people with sampling using saturated sampling technique. Saturated sampling is sampling if all members of the population are used as samples, if the population is less than 11 people. The technique of collecting data is by carrying out the VO2 Max test. One of the measuring tools that can measure a person's VO2 max ability is to use a multistage fitness test (bleep test). Before the multistage fitness test was used in data collection(Fenanlampir, 2015)

Preparation section :

1) Test takers must be healthy

2) Test takers must not be physically or mentally disabled

3) must wear sports clothes

a. Equipment and facilities

1) Tape recorder

2) Bleep test guide cassette

3) Distance limit sign

4) Bleep test form

5) 20 meters long track

6) Meter

7) Pen

b. Implementation

1) The second part of the distance between the two signals is the "tut" sound, which accurately marks the measured one-minute interval

2) Briefly introduce the implementation of the countdown test

3) Contestants must cross the boundary line every time they complete a distance of 20 meters

4) Each examinee runs as fast as possible according to the specified acceleration

5) If the participant fails to reach 2 steps or less than 20 meters after making a "tut" sound, the person 
who records the data will give a tolerance of $1 \times 20$ meters to complete the acceleration.

6) If the participant fails to adjust the acceleration during the trial period, he must be dismissed

7) For more detailed information, the author then gives an example to participants on how to run a multi-level running test

c. Determine the amount of VO2 Max

The amount of $\mathrm{VO} 2$ max is calculated based on the level and shuttle that can be achieved by the test taker, and is completed based on the VO2 max table. In measuring $\mathrm{VO} 2 \max$, the researcher was assisted by Tim.

\section{d. Norm Bleep Tes}

According to the Indonesian Wikipedia, a formula is a short way to find certain information by using a benchmark, which is symbolized by letters, numbers, or signs. The formula can also be interpreted as a statement or conclusion on the establishment or determination which is called a concise and precise sentence. Formulas are often also said to be one of the steps or scientific methods to reach or seek conclusions or as concepts. Norms of oxygen consumption level test based on age are as follows:

Table 1.

\begin{tabular}{lllll}
\hline Category & \multicolumn{2}{l}{$\begin{array}{l}\text { Maximum } \\
\text { consumption }\end{array}$} & oxygen \\
\hline & $<30$ & $30-$ & $40-$ & $>50$ \\
& Year & 39 & 49 & Year \\
& $\mathrm{s}$ & Year & Year & $\mathrm{s}$ \\
& & $\mathrm{s}$ & $\mathrm{s}$ & \\
\hline Very & $<25$. & $<25$. & $<25$. & \\
bad & 0 & 0 & 0 & \\
\hline Bad & $25.0-$ & $25.0-$ & $25.0-$ & $>25$. \\
& 33.7 & 30.1 & 26.4 & 0 \\
\hline Currentl & $33.8-$ & $30.2-$ & $26.5-$ & $25.0-$ \\
y & 42.5 & 39.1 & 35.4 & 33.7 \\
\hline
\end{tabular}

\begin{tabular}{lllll}
\hline Well & $42.6-$ & $39.3-$ & $35.5-$ & $33.8-$ \\
& 51.5 & 48 & 45.0 & 43.0 \\
\hline Very & $>51$. & $>48$ & $>45$. & $>43$. \\
good & 6 & & 1 & 1 \\
\hline
\end{tabular}

Source : (Fenanlampir, 2015)

Table 2.

Multi-Stage Running VO2Max Score Table (Bleep Test)

\begin{tabular}{|c|c|c|c|c|c|}
\hline \multicolumn{2}{|c|}{ |evel shuttle } & $\begin{array}{l}\text { VO2 } \\
\text { Max }\end{array}$ & level & shuttle & $\begin{array}{l}\text { VO2 } \\
\text { Max }\end{array}$ \\
\hline 4 & 2 & 26.8 & 15 & 2 & 64.6 \\
\hline 4 & 4 & 27.6 & 15 & 4 & 65.1 \\
\hline 4 & 6 & 28.3 & 15 & 6 & 65.6 \\
\hline 4 & 9 & 29.5 & 15 & 8 & 66.2 \\
\hline 5 & 2 & 30.2 & 15 & 10 & 66.7 \\
\hline 5 & 4 & 31 & 15 & 13 & 67.5 \\
\hline 5 & 6 & 31.8 & 16 & 2 & 68 \\
\hline 5 & 9 & 32.9 & 16 & 4 & 68.5 \\
\hline 6 & 2 & 33.6 & 16 & 6 & 69 \\
\hline 6 & 4 & 34.3 & 16 & 8 & 69.5 \\
\hline 6 & 6 & 35 & 16 & 10 & 69.9 \\
\hline 6 & 8 & 35.7 & 16 & 12 & 70.5 \\
\hline 6 & 10 & 36.4 & 16 & 14 & 70.9 \\
\hline 7 & 2 & 37.1 & 17 & 2 & 71.4 \\
\hline 7 & 4 & 37.8 & 17 & 4 & 71.9 \\
\hline 7 & 6 & 38.5 & 17 & 6 & 72.4 \\
\hline 7 & 8 & 39.2 & 17 & 8 & 72.9 \\
\hline 7 & 10 & 39.9 & 17 & 10 & 73.4 \\
\hline 8 & 2 & 40.5 & 17 & 12 & 73.9 \\
\hline 8 & 4 & 41.1 & 17 & 14 & 74.4 \\
\hline 8 & 6 & 41.8 & 18 & 2 & 74.8 \\
\hline 8 & 8 & 42.4 & 18 & 4 & 75.3 \\
\hline 8 & 11 & 43.3 & 18 & 6 & 75.8 \\
\hline 9 & 2 & 43.9 & 18 & 8 & 76.2 \\
\hline 9 & 4 & 44.5 & 18 & 10 & 76.7 \\
\hline 9 & 6 & 45.2 & 18 & 12 & 77.2 \\
\hline 9 & 8 & 45.8 & 18 & 15 & 77.9 \\
\hline 9 & 11 & 46.8 & 19 & 2 & 78.3 \\
\hline 10 & 2 & 47.4 & 19 & 4 & 78.8 \\
\hline 10 & 4 & 48 & 19 & 6 & 79.2 \\
\hline 10 & 6 & 48.7 & 19 & 8 & 79.7 \\
\hline 10 & 8 & 49.3 & 19 & 10 & 80.2 \\
\hline 10 & 11 & 50.2 & 19 & 12 & 80.6 \\
\hline 11 & 2 & 50.8 & 19 & 15 & 81.3 \\
\hline 11 & 4 & 51.4 & 20 & 2 & 81.8 \\
\hline 11 & 6 & 51.9 & 20 & 4 & 82.2 \\
\hline 11 & 8 & 52.5 & 20 & 6 & 82.6 \\
\hline 11 & 10 & 53.1 & 20 & 8 & 83 \\
\hline 11 & 12 & 53.7 & 20 & 10 & 83.5 \\
\hline 12 & 2 & 54.3 & 20 & 12 & 83.9 \\
\hline 12 & 4 & 54.8 & 20 & 14 & 84.3 \\
\hline 12 & 6 & 55.4 & 20 & 16 & 84.8 \\
\hline
\end{tabular}




\begin{tabular}{cccccc}
\hline 12 & 8 & 56 & 21 & 2 & 85.2 \\
\hline 12 & 10 & 56.5 & 21 & 4 & 85.6 \\
\hline 12 & 12 & 57.1 & 21 & 6 & 86.1 \\
\hline 13 & 2 & 57.6 & 21 & 8 & 86.5 \\
\hline 13 & 4 & 58.2 & 21 & 10 & 86.9 \\
\hline 13 & 6 & 58.7 & 21 & 12 & 87.4 \\
\hline 13 & 8 & 59.3 & 21 & 14 & 87.8 \\
\hline 13 & 10 & 59.8 & 21 & 16 & 88.2 \\
\hline 13 & 13 & 60.6 & & & \\
\hline 14 & 2 & 61.1 & & & \\
\hline 14 & 4 & 61.7 & & & \\
\hline 14 & 6 & 62.2 & & & \\
\hline 14 & 8 & 62.7 & & & \\
\hline 14 & 10 & 63.2 & & & \\
\hline 14 & 13 & 64 & & & \\
\hline \multicolumn{7}{c}{}
\end{tabular}

\section{Data analysis technique}

The data obtained were analyzed using descriptive analysis which aims to describe the level of VO2max in sepak takraw athletes. In this descriptive analysis of each variable, the data is displayed in the form of frequency distributions and diagrams. In this study, to analyze the data using the Vo2max program.

\section{RESULT}

The purpose of this study was to determine the Maximum Oxygen Volume (VO2MAX) in sepak takraw athletes. The data obtained from the multi-level bleep test. After that it was categorized into five categories, namely, very good, good, moderate, less and very less,

Description Maximum Oxygen Volume (Vo2max) Test Result Data For Sepak Takraw Athletes

The research data for the maximum oxygen volume score
(VO2MAX), it was found that the highest score was 41 and the lowest score was 37.1 VO2MAX. From the data analysis obtained the average price (Mean) of38.85. Frequency distribution of maximum oxygen volume data (VO2MAX) as shown in the table below.

Table 3.

\begin{tabular}{|c|c|c|c|}
\hline No & Name & $\begin{array}{l}\text { Vo2max } \\
\text { Results }\end{array}$ & category \\
\hline 1 & An & 37.8 & Currently \\
\hline 2 & ap & 39.2 & Currently \\
\hline 3 & Do & 41.1 & Currently \\
\hline 4 & $\mathrm{E}$ & 37.1 & Currently \\
\hline 5 & Er & 38.5 & Currently \\
\hline 6 & $\mathrm{Fe}$ & 39.9 & Currently \\
\hline 7 & $\mathrm{G}$ & 37.8 & Currently \\
\hline 8 & Jan & 40.5 & Currently \\
\hline 9 & M.A & 37.1 & Currently \\
\hline 10 & $\mathrm{Rz}$ & 39.2 & Currently \\
\hline 11 & Yo & 39.2 & Currently \\
\hline \multicolumn{2}{|c|}{ amount } & 427.4 & Currently \\
\hline \multicolumn{2}{|c|}{ mean } & 38.85 & Currently \\
\hline
\end{tabular}

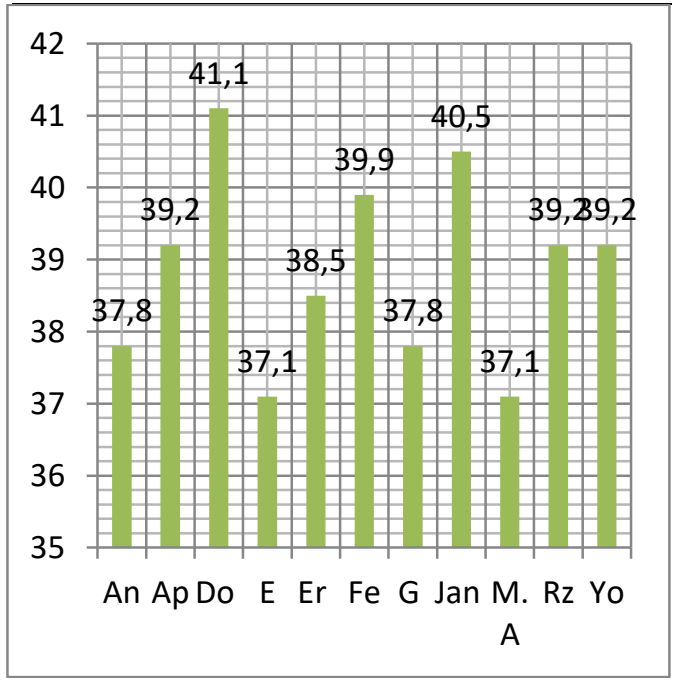

Picture. 1 Maximum Oxygen Volume Analysis Bar Chart

Based on the calculations listed in the table above, it can be explained that: on behalf of An with a maximum 
oxygen volume of 37.8 , on behalf of Ap with a maximum oxygen volume of 39.2, on behalf of Do with a maximum oxygen volume of 41.1 , on behalf of $\mathrm{E}$ with a maximum oxygen volume of 37.1, on behalf of Er with a maximum oxygen volume of 38.5 , on behalf of $\mathrm{Fe}$ with a maximum oxygen volume of 39.9 , on behalf of $\mathrm{G}$ with a maximum oxygen volume of 37.8 , on behalf of Jan with a maximum oxygen volume of 40.5, on behalf of MA with a maximum oxygen volume of 37.1 , on behalf of $\mathrm{Rz}$ with a maximum oxygen volume 39.2, on behalf of Yo with a maximum oxygen volume of 39.2.

Frequency Distribution by Category or Test Norms

Based on the test results, it can be seen that there are five categories of data, namely, very good, good, moderate, poor and very poor, these five categories are explained as follows: The norm of the Bleep test is to see a person's Maximum Oxygen Volume level.

Table 4. Bleep Test Norms

\begin{tabular}{lllll}
\hline Category & \multicolumn{2}{l}{$\begin{array}{l}\text { Maximum } \\
\text { consumption }\end{array}$} & \multicolumn{2}{l}{ oxygen } \\
\hline & $<30$ & $30-39$ & $40-49$ & $>50$ \\
& Years & Years & Years & Years \\
& & & & \\
\hline Very bad & $<25.0$ & $<25.0$ & $<25.0$ & \\
& & & & \\
\hline Bad & $25.0-$ & $25.0-$ & $25.0-$ & $>25.0$ \\
& 33.7 & 30.1 & 26.4 & \\
\hline Currently & $33.8-$ & $30.2-$ & $26.5-$ & $25.0-$ \\
& 42.5 & 39.1 & 35.4 & 33.7 \\
\hline Well & $42.6-$ & $39.3-$ & $35.5-$ & $33.8-$ \\
& 51.5 & 48 & 45.0 & 43.0 \\
\hline Very & $>51.6$ & $>48$ & $>45.1$ & $>43.1$ \\
good & & & & \\
\hline
\end{tabular}

Table 5. Test Norms From Research Results Seeing Maximum Oxygen Volume

\begin{tabular}{ccccc}
\hline No & test norm & $\begin{array}{l}\text { Interval } \\
\text { class }\end{array}$ & $\begin{array}{l}\text { Absolute } \\
\text { frequency }\end{array}$ & $\begin{array}{l}\text { Relative } \\
\text { Frequency }\end{array}$ \\
\hline 1 & Very bad & $<25.0$ & 0 & $0 \%$
\end{tabular}

\begin{tabular}{llllc}
\hline 2 & Bad & $\begin{array}{l}25.0- \\
33.7\end{array}$ & 0 & $0 \%$ \\
\hline 3 & Currently & $33.8-$ & 11 & $100 \%$ \\
& & 42.5 & & \\
\hline 4 & Well & $\begin{array}{l}42.6- \\
51.5\end{array}$ & 0 & 0 \\
& & & \\
\hline 5 & Very & $>51.6$ & 0 & 0 \\
& good & & &
\end{tabular}

The athletes' maximum oxygen uptake is as follows: In the very good category there are 0 athletes $(0 \%)$, in the good category there are 0 athletes $(0 \%)$, in the medium category there are 11 athletes $(100 \%)$, in the poor category there are 0 athletes $(0 \%)$ and very bad category there are 0 athletes $(0 \%)$

\section{DISCUSSION}

This research is a quantitative descriptive study where data collection uses a maximal oxygen volume test using the bleep test. The purpose of this study was to determine the maximum oxygen volume level. In takraw athletes. The athlete's maximum oxygen volume is in the moderate category because of training 5 times a week,In addition, during training, the trainer takes an active role in seeing and correcting what the child has done to find problems whichhas been given, in the form of exercises comparing with athletes how they do it, organizing 
and classifying as well as making conclusions and identifying when to find a match for a form of exercise. Errors from the review are corrected by the coach and show how a perfect movement is in practice.

Other factors that also have an important role in increasing achievement are internal factors, namely motivation and discipline fromin someone. Basically an activity, activity or behavior carried out by a person is always based on the existence of discipline and high motivation from within a person. To get good training results of course with the right method. In addition, external factors, namely coaches, environment, nutrition, facilities and infrastructure and others. Therefore, the ability of the trainer, both knowledge and skills, is very important to have, down to the smallest things in the field of the sport he trains. This knowledge includes mastery of technique, tactics and physical conditions.

\section{CONCLUSION}

Based on the results of research and discussion, it can be concluded that: Maximum Oxygen Volume Ability of SKO Sepak Takraw Athletes. With 11 samples and in the Medium category.

\section{Suggestions}

Based on the results of the research that has been done, the researchers hope and provide the following suggestions:

1. For athletes, so that athletes are more enthusiastic and earnest in participating in training later.

2. For the trainers later, the more the forms of training will be improved

3. For further researchers, they can develop this research by adding other elements that are wider

\section{REFERENCES}

Anusopati, A. E., Setiakarnawijaya, Y., \& Fitrianto, E. J. (2015). Pengaruh Latihan Jogging Terhadap Vo2max Pada Kelompok Hemoglobin Rendah Dan Normal Siswa Sma Negeri 8 Bogor. Jurnal Segar, 3(2).

Candra, O. (2020). Tingkat Kemampuan Vo2max Pada Atlet Bola Basket Puteri Pomnas Riau. Journal Sport Area, 5(2), 106115.

Https://Doi.Org/10.25299/Sportare a..Vol().3761

Fenanlampir, A. M. F. (2015). Tes Dan Pengukuran Dalam Olahraga - Andi Offset.

Hidayat, R., Budi, D. R., Purnamasari, A. D., Febriani, A. R., \& Listiandi, A. D. (2020). Faktor Fisik Dominan Penentu Keterampilan Bermain Sepak Takraw. Jurnal Menssana, 5(1), 33-39.

Hidayat, R., Sulaiman, S., \& Hidayah, T. (2016). Faktor Anthropometri, Biomotor Penentu Keterampilan Sepak Takraw Atlet Putra Pon Jawa Tengah. Journal Of Physical Education And Sports, 5(2), 83-88.

Maksum, H., Abdillah, A., \& Dewi, U. (2017). Pengaruh Latihan Formasi Berpusat Terhadap Keterampilan 
Servis Sepak Takraw. Jurnal Pendidikan Olah Raga, 6(2), 140146.

Nirwandi. (2018). Tinjauan Tingkat Vo

2 Max Pemain Sepakbola Sekolah Sepakbola Bima Junior Kota Bukittinggi. Jurnal Penjakora, 4(2), 18-27.

Pratama, S. M., \& Wiyaka, I. (2021). Profil Kondisi Fisik, Teknik, Dan Psikis Atlet Sepak Takraw. Jurnal Olahraga \& Kesehatan Indonesia, 1(2), 109-115.

Qurun, D. K. (2015). Hubungan Somatotype Dengan Kelincahan Atlet Sepak Takraw Upt Sma Negeri Olahraga Jawa Timur (Doctoral Dissertation, Universitas Airlangga).

Saputro, D. B., \& Supriyadi, S. (2017). Pengembangan Variasi Latihan Sepak Sila Sepak Takraw Untuk Tingkat Pemula. Indonesia Performance Journal, 1(2), 112118.

Siyoto, S., \& Sodik, M. A. (2015). Dasar Metodologi Penelitian -. Literasi Media Publish.

Sofyan, A. (2015). Sepak Takraw Untuk Pelajar. Pt Rajagrafindo Persada.

Syam, A. (2019). Analisis Kemampuan Inteligensi Atlet Cabang Olahraga Sepak Takraw Provinsi Gorontalo. Jambura Journal of Sports Coaching, 1(2), 79-90.

Wahyudhi, A. S. B. S. E., \& Fajarwati, S. (2020). Profil Mood Atlet Pra-
Pon Sepak Takraw Puteri Sulawesi

Tengah Dalam Melakukan

Latihan. Journal Sport Area, 5(2), 164-176.

Yunitaningrum, W. (2014).

Kemampuan Volume Oksigen

Maksimal Atlet Pusat Pendidikan

Dan Latihan Pelajar Sepak Takraw

Kalimantan Barat. Media Ilmu

Keolahragaan Indonesia, 4(2), 63-

67. 